\title{
FACTORS THAT INFLUENCE THE INTENSITY OF THE USE OF DIGITAL PAYMENT (CASE STUDY IN OVO USERS)
}

\author{
Triyani Budyastuti \\ Mercu Buana University \\ Jakarta, Indonesia
}

Article DOI: https://doi.org/10.36713/epra4614

\begin{abstract}
The purpose of this study is to analyze the factors that influence the intensity of the use of digital payments, especially users of OVO applications. Factors that are suspected to have an influence on the intensity of the use of digital payments in OVO applications are perceived ease of use, perceived risk of use, perceived usefulness of use and trust.

The population in this study were all students of the Faculty of Economics, University of Mercu Buana and students of the Faculty of Economics, University of Prof. Dr. Moestopo (Beragama). Sampling was carried out by random sampling method totaling 115 respondents, 60 respondents from the Faculty of Economics, University of Mercu Buana and 55 respondents from the Faculty of Economics, University of Prof. Dr. Moestopo (Beragama). The primary data collection method used is the questionnaire method. Data analysis technique used in this study is multiple regression analysis techniques with test equipment using PLS 3.0.
\end{abstract}

KEYWORDS: Usefulness, Risk, Ease of Use, Trust, Intensity Use of digital payment

\section{INTRODUCTION}

The digital industry in Indonesia continues to show its development. The impact of fintech advancements is presenting digital payment innovation or better known as Digital Payment. Digital payments that are developing in kind are as varied as e-money, e-wallet, and so on.

Urban communities in Indonesia are getting very used to using non-cash payment facilities. Noncash payments are currently enforced specifically in the field of transportation such as toll, busway and train ticket payments. Digital payment in Indonesia makes it easy in the midst of busy daily activities. Various payment needs have now been made through

debit card, credit card, m-bankrupt, e-banking, paypal, prepaid cards, and so on. However, variations in digital payments continue to develop from time to time. All the needs of the Indonesian people will undoubtedly continue to grow and vary in variety. In terms of mini transactions, the witness was on a massive scale to meet all needs for the welfare of life.

E-money or Electronic money may not be something that sounds familiar to us. As referred to in Bank Indonesia Regulation Number: 11/12 / PBI / 2009 concerning Electronic Money which has now been updated to PBI Number: 18/17 / PBI / 2016, Emoney is issued on the basis of the value of money deposited in advance by holders to the issuer and the value of the money is stored electronically in a medium such as a server or chip. E-money is not only a substitute for physical cash in the form of coins and paper money with equivalent electronic money, but also as a system that allows a person to pay for goods or services by sending numbers from one computer to a computer. The digital industry in Indonesia continues to show its development. The impact of advancing fintech presents digital payment innovation or better known as Digital Payment. Digital payments that are developing in kind are as varied as e-money, e-wallet, and so on. Urban communities in Indonesia are getting very used to using non-cash payment facilities. Non-cash payments are currently enforced specifically in the field of transportation such as toll, busway and train ticket payments.

Digital payment in Indonesia makes it easy in the midst of busy daily activities. Various payment needs have now been made through

debit card, credit card, m-bankrupt, e-banking, paypal, prepaid cards, and so on. However, variations in digital payments continue to develop from time to time. All the needs of the Indonesian people will undoubtedly continue to grow and vary in variety. In terms of mini transactions, the witness was on a massive scale to meet all needs for the welfare of life. 
E-money or Electronic money may not be something that sounds familiar to us. As referred to in Bank Indonesia Regulation Number: 11/12 / PBI / 2009 concerning Electronic Money which has now been updated to PBI Number: 18/17 / PBI / 2016, Emoney is issued on the basis of the value of money deposited in advance by holders to the issuer and the value of the money is stored electronically in a medium such as a server or chip. E-money is not only a substitute for physical cash in the form of coins and paper money with equivalent electronic money, but also as a system that allows a person to pay for goods or services by sending numbers from one computer to another.

The emergence of e-money in society which aims to reduce the growth rate of cash usage. Specifically for micro and retail payments.

Bank Indonesia (BI) ensures the smooth payment system is maintained both in terms of cash and non-cash in February 2019. Especially for noncash payments, BI revealed a sharp increase. But BI has not released the exact numbers. "The use of electronic money has grown to 66.6 percent (compared to February 2019)." said Executive Director of the BI Communication Department Onny Widjanarko in a press release, Jakarta, Thursday (3/21/2019). (Kompas, 2019).

While the latest data from Bank Indonesia (BI) shows, the value of digital money transactions during July 2019 then totaled Rp 12.93 trillion. This figure jumped $262.67 \%$ compared to the same month in 2018 which was only $\mathrm{Rp} 3.58$ trillion. The electronic money transaction in July was at once the highest monthly value of all time, with a transaction volume of 476,037,115 times. The highest electronic money transaction value previously occurred in May 2019 amounting to $\mathrm{Rp} 12.81$ trillion. Transaction volume reached 422,602,216 times.

An increase in terms of information technology services and infrastructure creates various lifestyle changes in society. Changes occur in various sectors, ranging from the number of new business models to changes in demand for the ability of the workforce. These changes require some adjustments. One of them is an effort to improve people's digital literacy. The low understanding of security and the unclear rules regarding privacy in cyberspace increase the risks that arise, so that there are still many people who do not fully trust to shop online.

According to Anistasya Kristina, Vice President of Corporate Communications at PT Nusa Satu Inti Artha (Doku), there are two biggest challenges in developing payment services. First, cyber security is still a common challenge for all tech players in the ecommerce ecosystem anywhere in Indonesia. Second, education about the benefits of payment service products and technologies requires time and synergy between industry players and regulators in order to achieve common goals. Indonesia must prepare itself from the onslaught of foreign players who want to seize the domestic market. For this reason, much improvement must be done, especially solving a number of issues that could make the development of e-commerce in Indonesia stagnant. Therefore, trust \& security is still a big challenge that must be resolved together.

In some of the problems that have been mentioned, it clearly illustrates that the use of a technology cannot be separated from user needs. Jogiyanto (2007: 29) defines intention (intention) as the desire to conduct behavior. Behavior is an action that is carried out significantly, in other words behavior here is behavior in using the media to meet their needs. If the use of information technology can meet their needs, then the attitude of users tends to accept the technology and can cause interest in using information technology. This is where the role of users in the use of information technology is very important, so to know the level of user acceptance (user) of an information technology it is necessary to know about the factors that influence individual acceptance of the use of information technology. To find out and measure how much perception of the benefits and usefulness of information systems, how simple and easy the information system is practiced and how much performance improvement can be achieved thanks to the existence of the information system, can use the Technology Acceptance Model (TAM) model.

The Technology Acceptance Model (TAM) is a model that offers an explanation for the acceptance of the use of technology (e-commerce) and the behavior of its users (Davis, 1989). The Technology Acceptance Model in Davis (1993), is defined as one of the models built to analyze and understand the factors that influence the acceptance of the use of information technology. Many factors affect the interest in using digital payment by individuals, including factors ease, usability, value received, social influence, risk, and trust. Based on research conducted by Pavlou (2003), by taking constructs in the exogenous latent variables used, namely ease of use and usefulness as the main constructs in TAM theory and trust as additional constructs.

Based on the background above, the researcher wants to examine what individual perceptions affect the intensity of using digital payment. In this case the researchers took research sources from the research of Dwi Marcelina (2014), Mustofa Abdul Karim (2018), Ana Fitriana (2017), Adinda Cahaya Mentari (2018) and Anjelina (2018). Anjelina (2018) conducted a study on consumer perceptions of emoney usage which showed that risk and price had a negative effect on consumer intentions / to reuse digital payment. Dwi Marcelina (2014), Mustofa Abdul Karim (2018), Ana Fitriana (2017), Adinda Cahaya Mentari (2018) showed that the Technology Acceptance Model factors had a positive and significant effect on the use of electronic money. 
By using the Technology Acceptance Model approach, the researcher wants to realize the research in the form of a thesis with the title "FACTORS THAT INFLUENCE THE INTENSITY OF THE USE OF DIGITAL PAYMENT (Case Study on OVO Application Users)"

\section{LITERATURE REVIEW \\ Technology Acceptance Model (TAM)}

Technology Acceptance Model (TAM) which is also called the Technology Acceptance Model is one of the theories about the use of information technology systems that are considered very influential and are generally used to explain individual acceptance of the use of information technology systems (Jogiyanto, 2007: 111). TAM (Technology Acceptance Model) was first introduced by Davis in 1989. The Technology Acceptance Model in Davis (1993), is defined as one of the models built to analyze and understand the factors that influence the acceptance of the use of information technology.

\section{a. Behavioral Intentions to Use (Interest in Behavior Using Technology)}

Intentions / Intentions are behavioral tendencies that are carried out with ease and not without purpose. Fishbein and Ajzen (1969) explain intention / intention as cognitive and conative representations of an individual's readiness to display a behavior. Intention is a determinant and disposition of behavior, until the individual has the opportunity and time to display the behavior clearly (Ratna. C.S, 2018: 294). Behavioral Intention to Use is the tendency of behavior to keep using a technology. The level of use of a computer technology on someone can be predicted attitudes of attention to the technology, for example, the desire to add supporting peripherals, motivation to keep using, and the desire to motivate other users (Davis, 1989: 321).

\section{b. Perceived Ease of Use}

In Davis (1989), perceived ease of use of a technology is defined as a measure by which a person believes that technology can be easily understood and used. Trust is needed by users of information technology in order to improve the performance of individuals in carrying out organizational or corporate activities.

\section{c. Perceived Usefulness}

Perceived usefulness is defined as the extent to which a person believes that using a technology will improve the performance of his work ("as the extent to which a person believes that using a technology will enhance her or his performance.") That is, if someone feels confident that the information system is useful then he will use it. Conversely, if you believe that the information system is less useful he will not use it. In other words, this construct is a belief (belief) about the decision making process (Jogiyanto, 2007: 114).

\section{d. Perceived Risk of Use}

According to Faiz Zamzami (2018: 235) the more sophisticated the development of internet technology, the more threats and risks that may arise. Therefore, security of information and transactions, becomes the main thing that must be considered by companies that implement e-commerce.

\section{e. Trust}

Trust is needed by users of information technology in order to improve the performance of individuals in carrying out organizational or corporate activities. Trust is a tool for leveraging the sustainability of a business, especially those implementing e-commerce, therefore, it is important for companies to prevent and control the threats and risks of electronic transactions (Faiz, et al, 2018: 236). Trust is also very much needed in online purchasing decisions by consumers, as expressed by Febrina Mahliza (2020).

\section{Non-Cash Payment Systems (Digital Payment)}

The government in 2017 is increasingly aggressively promoting non-cash transactions including the use of electronic money. Evidenced by the government issued regulations regarding electronic money. The regulation is "Bank Indonesia Regulation Number 18/17 / Pbi / 2016 concerning the Second Amendment to Bank Indonesia Regulation Number 11/12 / Pbi / 2009 concerning Electronic Money". the regulation was made to increase the use of electronic money and support financial inclusion.

The types of e-payment are:

a. Electronic Cash (Electronic - cash): transactions are completed through electronic currency exchanges.

b. Prepaid Cards: customers use prepaid cards for a certain amount by making entries from a unique card number on the merchant's site. The value of the card decreases with the amount paid to the merchant.

c. Credit Card: the server authenticates the consumer and verifies with the bank whether sufficient funds are available before purchase; payment is posted on the customer's account and the customer is billed later for this payment and pays the account balance to the bank.

d. Debit Card: the customer maintains a positive account balance, and money is deducted from the account when the debit transaction is made.

e. Electronic Check: An institution electronically completes a transaction between the buyer's bank and the seller's bank in the form of an electronic check.

E-payment offers a variety of benefits such as speeding up the transaction process and being able to sell products at lower prices. The parties involved in the transaction process can transfer and receive money from other parties anytime, anywhere. In 
addition, e-payment can also support the movement of green technology where paper usage can be reduced.

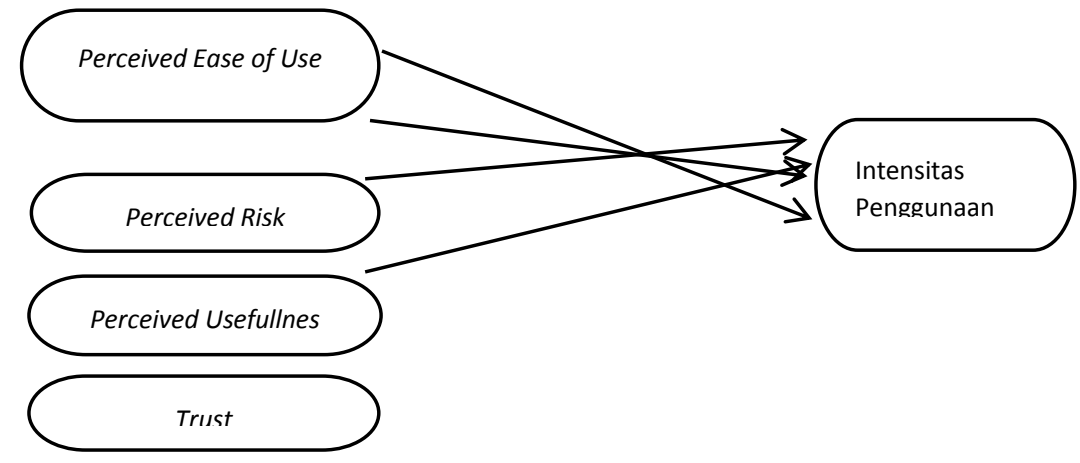

Gambar 2.1

Kerangka Konseptual Penelitian

\section{HYPOTHESIS}

Based on the problem formulation that has been described above, the hypothesis of this study is as follows:

1. Perceived Ease of Use affects the intensity of Digital Payment Usage

2. Perceived Risk influences the intensity of Digital Payment Usage

3. Perceived Usefulness affects the intensity of Digital Payment Usage

4. Trust has an influence on the use of Digital Payment Intensity

\section{METHODOLOGY}

In the framework of this study researchers used the Causal research method. Causal research is used to prove the relationship between cause and effect of several variables. Causal research usually uses the experimental method by controlling the independent variables that will affect the dependent variable. In this study, designed to determine and describe the relationship between perceived ease of use, perceived usefulness of use, perceived risk of use and trust in the intensity of digital payment use. 
Tabel 4.1

Definisi Operasional Variabel Penelitian

\begin{tabular}{|c|c|c|c|}
\hline No & Nama Variabel & Indikator & $\begin{array}{c}\text { Skala } \\
\text { Pengukuran }\end{array}$ \\
\hline 1 & $\begin{array}{c}\text { Intensitas } \\
\text { penggunaan }(\mathrm{Y})\end{array}$ & 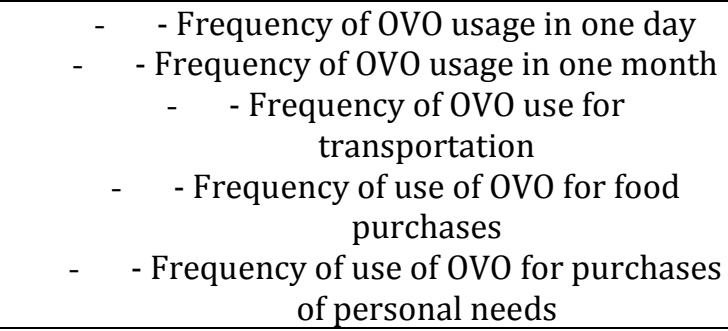 & Interval \\
\hline 2 & $\begin{array}{l}\text { Perceived Ease of } \\
\text { Use (X1) }\end{array}$ & $\begin{array}{c}\text { - It's easy to learn how to use a non-cash } \\
\text { payment system } \\
\text { - Do not use a large effort to make non-cash } \\
\text { payments } \\
\text { - Very easy to use to make ends meet } \\
\text { - Easily operate the system according to what } \\
\text { individuals want to do } \\
\text { - Overall the online payment system is very easy } \\
\text { to do }\end{array}$ & Interval \\
\hline 3 & $\begin{array}{l}\text { Perceived Risk of } \\
\text { Use (X2) }\end{array}$ & $\begin{array}{l}\text { - Security level of non-cash payment systems } \\
\text { - Guaranteed risk } \\
\text { - Feel you have a small risk to buy products at a } \\
\text { large price using non-cash payments }\end{array}$ & Interval \\
\hline 4 & $\begin{array}{c}\text { Perceived } \\
\text { Usefullness of Use ( } \\
\text { X3 ) }\end{array}$ & $\begin{array}{l}\text { - The use of systems can improve individual } \\
\text { work } \\
\text { - The use of the system is able to save energy } \\
\text { - The use of the system is very beneficial for } \\
\text { individuals } \\
\text { - The use of the system can reduce the time to } \\
\text { transact } \\
\text { - Overall the online payment system is very } \\
\text { useful }\end{array}$ & Interval \\
\hline 5 & Trust (X4) & $\begin{array}{l}\text { - Trust that the provider of a non-cash payment } \\
\text { system is honest } \\
\text { - Trust that the provider of a non-cash payment } \\
\text { system provides secure services } \\
\text { - Trust that the system provider is able to limit } \\
\text { unauthorized people to access the payment } \\
\text { system } \\
\text { - Trust that personal data is safe when using a } \\
\text { non-cash payment service } \\
\text { - Overall trust in online payment systems }\end{array}$ & Interval \\
\hline
\end{tabular}




\section{POPULATION AND RESEARCH SAMPLES}

The population in this study were students of FEB Mercu Buana University and FEB Prof. University DR. Moestopo (Beragama). The method used in sampling is included in non-probability sampling, namely convenience sampling. Due to the absence of a definite number in the population of all OVO users, the determination of the sample of researchers is based on the opinion of Sekaran (2017: 87 ) where the sample size is more than 30 and less than 500 is appropriate for most studies. Researchers took a sample of 115 respondents consisting of FEB Mercu Buana University students and Prof. FEB University DR. Moestopo (Beragama).

\section{Data Analysis Methods}

Data analysis is a procedure or process of activities within

summarize data collected from research results so that the data can be processed into a form that is more understood by the reader. In this study the questionnaire analysis used the Likert scale 1-5, using the SmartPLS3 (Partical Least Square version 3) software.

\section{RESULTS}

\section{Hypothesis Test}

\section{Evaluation of the Outer Model a. Convergent Validity Test}

Convergent validity measurement aims to determine the validity of each relationship between the indicator and its latent variable. Convergent validity of the measurement model with reflexive indicators can be seen from the correlation between item / indicator scores and construct scores. Individual indicators are considered reliable if they have a correlation value above 0.70 . However, at the scale development research stage, loading 0.50 to 0.60 is still acceptable. (Ghozali, 2014).

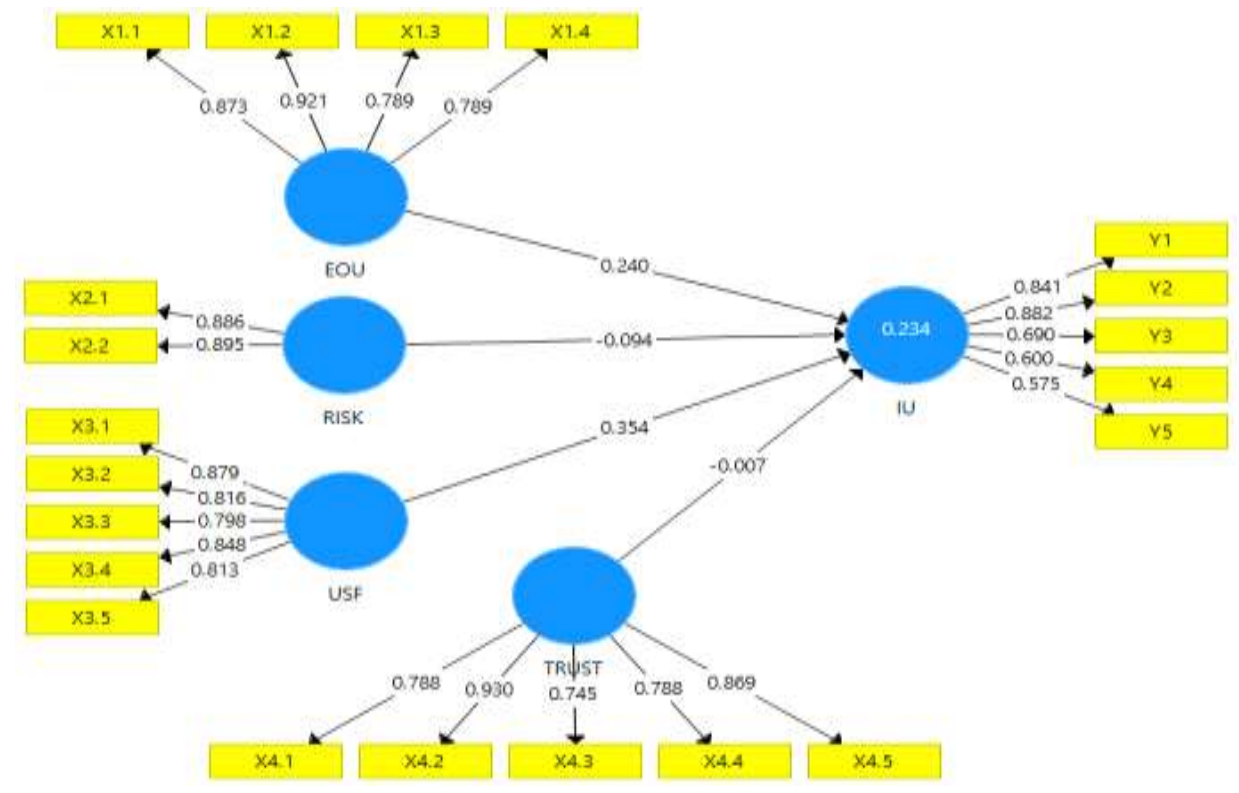

Figure 5.1

PLS-Algorithm Model after Convergent Validity Test 1

Source: PLS Data Processing 3.0 (2020)

\section{b. Cross Loading (Discriminant Validity)}

Discriminant Validity of the measurement model with reflex indicators is assessed based on cross loading measurements with constructs. If the correlation constructs with measurement items are greater than other constructs, then this shows that latent constructs predict the size of their block better than the size of the other blocks (Ghozali, 2014).

From the discriminant validity test above, Cross Loading has shown that latent constructs predict indicators in their blocks better than indicators in other blocks. In other words, it can be seen that the cross loading Correlation Value with the latent variable is appropriate, which is greater than the correlation with other latent variables.

Another method for assessing discriminant validity is by comparing the square root of the average variance extracted (AVE) for each construct and the correlation between the construct and the other constructs in the model. The model has sufficient discriminant validity if the root of AVE for 
EPRA International Journal of Multidisciplinary Research (IJMR) - Peer Reviewed Journal Volume: 6 | Issue: 6 | June 2020 || Journal DOI: 10.36713/epra2013 || SJIF Impact Factor: 7.032 ||ISI Value: 1.188

Table 5.1

Descriminant Validity Test Results (Fornell Lacker Criterion)

\begin{tabular}{|l|c|c|c|c|c|}
\hline Variabel & EOU & IU & RISK & TRUST & USF \\
\hline Perceived Ease Of Use (EOU) & 0,845 & & & & \\
\hline Intensitas Penggunaan (IU) & 0,397 & 0,728 & & & \\
\hline Resiko (Risk) & 0,455 & 0,178 & 0,890 & & \\
\hline Kepercayaan (Trust) & 0,510 & 0,290 & 0,262 & 0,827 & \\
\hline Perceived Usefulness (USF) & 0,576 & 0,444 & 0,465 & 0,563 & 0,831 \\
\hline
\end{tabular}

Source: PLS Data Processing 3.0 (2020)

From table 5.1 it can be concluded that the average variance extracted square root (AVE) is $0831,0.827,0.890,0.728$ and 0.845 . These values are greater than the correlation of each construct. So there is no problem Discriminant Validity in the model that has been tested.

\section{c. Average Variance Extraced (AVE)}

Another test is to assess the validity of the construct by looking at the value of AVE, a good model is required if at AVE each of the other constructs is greater than 0.5 (Ghozali, 2014).

Table 5.2 - Test Results for Average Variance Extraced (AVE)

\begin{tabular}{|l|l|}
\hline Variabel & AVE \\
\hline Perceived Ease Of Use (EOU) & $\mathbf{0 , 7 1 3}$ \\
\hline Intensitas Penggunaan (IU) & $\mathbf{0 , 5 3 0}$ \\
\hline Resiko (Risk) & $\mathbf{0 , 7 9 2}$ \\
\hline Kepercayaan (Trust) & $\mathbf{0 , 6 8 4}$ \\
\hline Perceived Usefulness (USF) & $\mathbf{0 , 6 9 1}$ \\
\hline
\end{tabular}

Source: PLS Data Processing 3.0 (2020)

Meanwhile, Cronbach alpha is said to be good if $\alpha \geq 0.5$ and said to be sufficient if $\alpha \geq 0.3$. (Latan and Ghozali, 2015)

The reliability test results using Composite Reliability and Chronbach Alpha in this study using the SPLS Algorithma and the report results are as follows:

AVE output results show that the AVE value is good for the construct of Perceived Ease of Use (EOU), Intensity of Use (IU), Risk (Risk), Trust (Trust), Perceived Usefulness (USF), has a value of AVE greater than 0.50. So the AVE value for all constructs is good.

\section{d. Reliability Test using Composite Reliability and Chronbach Alpha}

Besides the construct validity test, a construct reliability test is also measured by two criteria, namely composite reliability and Cronbach alpha of the indicator block that measures the construct. To determine the composite reliability, if the composite reliability value $\rho c>0.7$ can be said that the construct has a high reliability or reliable (Ghozali, 2014). 
Table 5.3

Reliability Test uses Composite Reliability and Chronbach Alpha

\begin{tabular}{|l|c|c|}
\hline & Cronbach's Alpha & Composite Reliability \\
\hline EOU & 0,864 & 0,908 \\
\hline IU & 0,768 & 0,846 \\
\hline RISK & 0,738 & 0,884 \\
\hline TRUST & 0,885 & 0,915 \\
\hline USF & 0,888 & 0,918 \\
\hline
\end{tabular}

Source: PLS Data Processing 3.0 (2020)

The results of the Reliability Test output using Compostie Reliability and Chronbach Alpha are good for constructs AVE output results show that AVE values are good for constructs of Perceived Ease of Use (EOU), Intensity of Use (IU), Risk (Risk), Trust, Trust and Usefulness USF), is very good because Composite Reliability is above 0.70 and Chronbach Alpha is above 0.6 so that it can be concluded that all construct indicators are reliable or meet the reliability test.

\section{Inner Model Evaluation (Structural Model)}

a. R Square Test

In assessing structural models with PLS, it starts by looking at the R-Square value for each endogenous latent variable as the predictive power of the structural model. The inner model is the specification of the relationship between latent variables (structural models), also called inner relations, showing the relationship between latent variables based on substantive theory from research. R2 results of 0.67 ; 0.33 ; and 0.19 ; indicate that the models "Good", "Moderate", "Weak" (Ghozali, 2014)

Tabel 5.4

Hasil Uji R Square

\begin{tabular}{|l|l|}
\hline & R Square \\
\hline IU & 0,234 \\
\hline
\end{tabular}

Source: PLS Data Processing 3.0 (2020)

Based on the coefficient of determination in the table above, it shows the R2 value of the Usage Intensity variable (IU), amounting to 0.234 which means that this value can indicate that the endogenous variable Intensity of Use (IU), can be explained by an exogenous variable namely Perceived Ease of Use (EOU), Risk (EOU), Risk Risk), Trust (Trust), Perceived Usefulness (USF). In this study R2 was $23.4 \%$ while the remaining $76.6 \%$ was influenced by other variables not contained in the research model. Evaluation of the inner model R2 is included in the Weak category in explaining the Intensity of Use (IU) variable.

\section{b. Hypothesis test}

The next test is the Path Coefficient test to see the significance of Perceived Ease of Use (EOU), Risk (Risk), Trust (Trust), Perceived Usefulness (USF) on Intensity of Use (IU). To test the hypothesis in this study, partial t values were used in each direct influence path partially.

The results of this test will show significant results seen from the results of the Original Samples, tilapia probability and t-statistics. For the probability value, the $\mathrm{p}$-value is $5 \%$ alpha. Testing is done with the limit according to table t. The t-table value for alpha $5 \%$ is 1.96 . to accept the proposed hypothesis is more than 1.96, which if $t$ table of 5\% significance is in the range of values -1.96 and 1.96 then the hypothesis will be rejected. The t-statistic estimation results can be seen in the path coefficients. 
Table 5.5

Path Coefficient Test Results (Inner Model)

\begin{tabular}{|l|l|l|l|}
\hline & $\begin{array}{l}\text { Original } \\
\text { Sample (0) }\end{array}$ & $\begin{array}{l}\text { T Statistics } \\
(\mid \mathbf{0} / \text { STDEV })\end{array}$ & P Values \\
\hline EOU -> IU & 0,240 & 2,108 & $\mathbf{0 , 0 3 6}$ \\
\hline RISK $->$ IU & $-0,094$ & 0,893 & $\mathbf{0 , 3 7 2}$ \\
\hline TRUST $->$ IU & $-0,007$ & 0,066 & $\mathbf{0 , 9 4 7}$ \\
\hline USF $->$ IU & 0,354 & 3,023 & $\mathbf{0 , 0 0 3}$ \\
\hline
\end{tabular}

Source: PLS Data Processing 3.0 (2020)

In the table above, the effect of Ease of Use (EOU) on Intensity of Use (IU) with $P$ values of 0.036 is smaller than the significance level $\alpha=0.05$ $(5 \%)$. These results show that there is a significant positive effect between Ease of Use (EOU) on Intensity of Use (IU). Thus the first hypothesis (H1) which states that Ease of Use (EOU) has a positive effect on Intensity of Use (IU) can be accepted.

For the relationship between risk variables (RISK) and Intensity of Use (IU), the results in the table above show the $\mathrm{p}$ values of 0.372 greater than the significance level $\alpha=0.05(5 \%)$. Thus the second hypothesis (H2) which states that the Risk (RISK) has a positive effect on Intensity of Use (IU) is rejected.

For the relationship between the variable Usefulness (USF) on Intensity of Use (IU) with $\mathrm{p}$ values of 0.003 (smaller than the significance level $\alpha$ $=0.05)$. These results show that there is a significant positive effect between Usefulness (USF) on Intensity of Use (IU). Thus the third hypothesis (H3) which states Usefulness (USF) has a positive effect on Intensity of Use (IU) can be accepted.

For the relationship between the Trust variable and the Intensity of Use (IU), the p value of 0.947 is greater than the significance level $\alpha=0.05(5 \%)$. Thus the second hypothesis (H4) which states that Trust has a positive effect on Intensity of Use (IU) is rejected.

\section{DISCUSSION}

Ease of Use (EOU) has a positive effect on Intensity of Use (IU), this can be seen from the number of respondents who answered agreed and strongly agreed on all items of the variable ease of use question. Where respondents feel that the ovo application is easy to learn, easy to understand, does not require a large effort and in general the respondents state the use of ovo is easy to do. This is in line with research conducted by Ana Fitriana (2017) where her research proved that partially the Perceived Ease of Use factor was proven to influence the interests of Indomaret consumers using e-money.

Risk (RISK) does not have a positive effect on Intensity of Use (IU), this is because there are still many respondents who do not understand the risks of use and fully trust the OVO application both in terms of security and guarantee if there is a transaction risk. This is not in line with research conducted by Wahyuni Nur Syahril (2019) where her research supports the effect of risk perception on the use of non-cash payments in e-commerce applications.

Usefulness (USF) has a positive effect on Intensity of Use (IU), this can be seen from the number of respondents who answered agree and strongly agree with all the Usefulness variable question items, where respondents feel using ovo can increase payment effectiveness, save time and effort, and almost all respondents stated that the use of ovo was very beneficial. This is in line with research conducted by Anastasia and Febrian Kwarto (2018) where the results of the study stated that the benefits significantly influence the intensity of the use of efilling. As well as research conducted by Andika Bayu Pratama (2019) which states that perceived usefulness has a significant effect on interest in using electronic money.

Trust does not have a positive effect on Intensity of Use (IU), this is because there are still many respondents who do not yet believe in honesty and security both personal data on the security of OVO applications and security guarantees if there is a transaction risk. This is not in line with research conducted by Zlatko Bezhovski (2016) which states that trust has a positive effect on electronic payment systems.

\section{CONCLUSION}

From the discussion above it can be concluded that the Perceived Ease of Use and Perceived Usefulness have a positive effect on the intensity of use. Where respondents feel that the ovo application is easy to learn, easy to understand, does not require a lot of effort and in general the respondents state the use of ovo is easy to do and provides benefits including respondents being able to save time and energy and be effective in making payments. Risk and Trust do not affect the intensity of use. Where many respondents do not understand the risk of using and fully trust the OVO application both in terms of 
security and collateral if there is a transaction risk and lack of trust in the OVO application.

\section{SUGGESTIONS}

Researcher suggestions for future researchers:

1. Increase the number of samples studied and expand the research location so that it is expected that the level of generalization from the analysis will be more accurate and good.

2. Further research can also use other data collection methods such as direct interviews so that respondents can honestly answer questions.

\section{REFERENCES}

1. A Bayu Pratama, IDG Dharma Saputra. 2019. Pengaruh Persepsi Manfaat, Persepsi Kemudahan Penggunaan, dan Tingkat Kepercayaan Pada Minat Menggunakan Uang Elektronik. E-Jurnal Akuntansi Vol 27 No. 2

2. A Cahya Mentari. 2018. Analisis Faktorfaktor Yang Mempengaruhi Minat Dalam Menggunakan Uang Elektronik di Kota Denpasae, Provinsi Bali. E-Jurnal Ekonomi Pembangunan Vol 7 No 4 April 2018.

3. A Fitriana, I Wingdes. 2017. Analisi TAM terhadap Faktor-faktor yang Mempengaruhi Konsumen menggunakan e-Money Indomaret Card di Pontianak. Jurnal Techno.com Jilid 16.

4. A Lizkayundari, F Kwarto. 2018. Pengaruh persepsi pemahaman wajib pajak, manfaat, Kemudahan penggunaan, dan Kepuasan wajib pajak terhadap Penggunaan system efilling. Balance:Jurnal Akuntansi, Auditing dan Keuangan jilid 15

5. Ardyanto,Denni.dkk. 2015. Pengaruh Kemudahan dan Kepercayaan Menggunakan E-Commerce Terhadap Keputusan Pembelian Online (Survei Pada Konsumen www.petersaysdenim.com). Jurnal Administrasi Bisnis Vol. 22 No. 1 Mei 2015

6. Bezhovski, Zlatko. 2016. The Future of the Mobile Payment as Electronic Payment System. European Journal of Business and Management, Vol.8, No.8, 2016

7. Bimo Walgito. 2004. Pengantar Psikologi Umum. Yogyakarta: Andi Offset.

8. Budi. 2010. Sekilas Tentang Technology Acceptance Model (TAM). Artikel. www.statistikakomputasi.wordpress.com. (diakses tanggal 13 november 2015)

9. Chuck, L. B. 2002. Welcome to the dark side: how e-commerce, online consumer, and e-mail fraud rely on misdirection and misinformation. AP Mintz. Information Today Inc.

10. Clough, J. 2010. Principles of cybercrime. Edisi Pertama. Cambridge, UK: Cambridge University Press.
11.

Dailysocial, 2015. Potensi dan Tantangan E-commerce Indonesia tahun 2015. Artikel www.dailysocial.net. Diakses pada tanggal 12 September 2015, 19:35.

12. Davis, F.D. 1989. Perceived usefulness, perceived ease of use, and user acceptance of information technology. MIS Quarterly. Vol. 13(3). 319-40.

13. Davis, F.D. 1986. Perceived Usefulness, Perceived Ease of Us, and User Acceptance of Information Technology. MIS Quartely. pp. 319-340.

14. Engel, James. F. (1995). Perilaku Konsumen. Jakarta : Binapura Aksara.

15. Erna Ferrinadewi. 2008. Merek \& Psikologi Konsumen. Yogyakarta: Graha Ilmu.

16. F Mahliza. 2020. Consumers Trust in Online Purchase Decision. EPRA International Journal of Multidisciplinary Research (IJMR) Vol 6 Issue 2 Februari 2020

17. Hartono, Jogiyanto. 2007. Sistem Informasi Keperilakuan. Yogyakarta: Andi.

18. Heidjen, H., Van Der, V. T., danCreemers, M. 2003. Understanding Online Purchase Intentions: Contributing From Technology and Trust Perspectives. European Journal of Information System. 2003, (12), 41-48.

19. Hutagaol, J., Darussalam, dan Septriady, Danny. 2006. Kapita Selekta Perpajakan. Jakarta: Penerbit Salemba Empat.

20. Imam Ghozali. 2012. Structural Equation Modeling - Teori, Konsep dan Aplikasi dengan Program LISREL 8.54. Semarang: Badan Penerbit Universitas Diponegoro.

21. Imam Ghozali. 2013. Aplikasi Analisis Multivariate dengan Program SPSS. Semarang: Badan Penerbit Universitas Diponegoro.

22. Imamuddin,Moch. 2014. Pengaruh Persepsi Kemudahan (Perceived Ease Of Use) Dan Persepsi Kegunaan (Perceived Usefulness) Terhadap Penggunaan Aktual (Actual Usage) E-Commerce OLX.co.id. Skripsi. Universitas Pendidikan Indonesia

23. Jarvenpaa, S., L., Tractinsky, N., dan Vitale, M. 2000. Consumer Trust in An Internet Store. Information Technology and Management. Vol. 1(12), pp. 45-71.

24. Jati, N., J. 2012. Analisis Faktor-faktor yang Mempengaruhi Minat Pemanfaatan dan Penggunaan Sistem E-Ticket (Studi Empiris pada Biro Perjalanan di Kota Semarang). Skripsi. Semarang: Program Sarjana Fakultas Ekonomika dan Bisnis Universitas Diponegoro.

25. Jogiyanto, H.M. 2007. Sistem Teknologi Keperilakuan. Yogyakarta: Andi Offset.

26. Jogiyanto, H.M. 2011.Konsep dan Aplikasi Struktural Equation Modeling Berbasis Varian dalam Penelitian Bisnis. Yogyakarta: Unit Penerbit dan Percetakan STIM YKPN Yogyakarta.

27. Kamil, Islamiah. 2017. Faktor-faktor Yang Mempengaruhi Perilaku Penggunaan Sistem E.Commerce (Studi Kasus Pada 
EPRA International Journal of Multidisciplinary Research (IJMR) - Peer Reviewed Journal Volume: 6 | Issue: 6 | June 2020 || Journal D0I: 10.36713/epra2013 || SJIF Impact Factor: 7.032 ||ISI Value: 1.188

Mahasswa Universitas Prof. Dr. Moestopo (Beragama)). Jurnal KIA

28. Kim, DJ, Ferriny, DL \& Rao, HR. 2008. A trust-based consumer decision-making model in electronic commerce: The role of trust, perceived risk, and their antecedents. Decision Support Systems. vol. 44, pp. 544564.

29. Lui, H., K., dan Jamieson, R. 2003. Integrating Trust and Risk Perceptions in Business-to-Consumer Electronic Commerce with The Technology Acceptance Model. In European Conference on Information Systems 2003. Naples.

30. Nazar, M.R, dan Syahran. 2008. Pengaruh Privasi, Keamanan, Kepercayaan, dan Pengalaman terhadap Niat untuk Bertransaksi secara Online. Program Pasca Sarjana Universitas Gajahmada Yogyakarta.

31. Niki. 2015. Pengaruh Pengetahuan, Pemahaman dan Kesadaran PPN atas Barang Kena Pajak (BKP) Terhadap Pola Konsumsi Mahasiswa UPDN. Skripsi. Universitas Prof. Dr. Moestopo (Beragama).

32. Pavlou. 2002. Consumer Intention to Adopt Electronic Commerce Incorporating Trust and Risk in Technology Acceptance Model. Journal of Logistics Information Management.

33. Pavlou, P.A.2003. Consumer Acceptance of Electronic Commerce: Integrating Trust and Risk with the Technology Acceptance Model. International Journal of Electronic Commercel Spring 2003. Vol. 7(3), pp. 69103.

34. Perkembangan Sangat Pesat Regulasi Ecommerce sumber http://sp.beritasatu.com/ekonomidanbisnis/p erkembangan-sangat-pesat-regulasi-ecommerce-belum-siap/81675. Diakses pada tanggal 19 November 2015, 13:45.

35. Republika, 2015. Transaksi E-commerce Bisa Capai 312 Triliun. Artikel www. republika.co.id. Diakses pada tanggal 15 September 2015, 19:50.

36. Rofiq, Ainur. 2007. Pengaruh Dimensi Kepercayaan (Trust) Terhadap Partisipasi Pelanggan E-Commerce (Studi Pada Pelanggan E-Commerce di Indonesia). Skripsi. Universitas Brawijaya Malang.

37. Sisca Amalia. 2016. "Pengaruh Perceived of Cyber Fraud, Perceived Ease of Use dan Perceived Risk Terhadap Perilaku Penggunaan Sistem E-commerce”. Skripsi. Universitas Mercubuana

38. Saraswati, P., \& Baridwan, Z. 2012. Penerimaan Sistem E-commerce: Pengaruh kepercayaan, Persepsi Manfaat dan Persepsi Risiko. Skripsi. Universitas Brawijaya.

39. Riskinanto, anggar,dkk.2017. The Moderation Effect of Age on Adopting EPayment Technology. Procedia Computer
Science 124 (2017) 536-543. online at www.sciencedirect.com

40. Sekaran, U. 2006. Research Methods For Business: A Skill Building Appoarch. PT. Jakarta: Elex Media Komputindo.

41. Shomad, A. 2013. Pengaruh Kepercayaan, Persepsi Kegunaan, Persepsi Kemudahan, Dan Persepsi Risiko Terhadap Perilaku Penggunaan E-Commerce. Skripsi. Universitas Brawijaya

42. Sidharta, Iwan., \& Sidh, Rahmawati. 2012. Pengukuran Persepsi Manfaat dan Persepsi Kemudahan Terhadap Sikap Serta Dampaknya atas Penggunaan Ulang Online Shopping pada E-commerce. Jurnal Computech \& Bisnis. Vol. 8, No.2, pp. 92100.

43. Sugiyono. 2014. Metodologi Penelitian Kuantitatif, Kualitatif dan Kombinasi (Mixed Methods). Bandung: Alfabeta.

44. Tjini, S. S. Ayu., \& Baridwan, Z. 2012. Pengaruh Kepercayaan, Persepsi Kegunaan, Persepsi Kemudahan, dan Persepsi Kenyamanan Terhadap Minat Penggunaan Sistem Internet Banking. Skripsi. Universitas Brawijaya.

45. Warr, M. 2000. Fear of crime in the United States: avenues for research and policy. Criminal Justice. vol. 4, pp.451-489W Nur Syahril \& B, Rikumuhu. 2019. Penggunaan Technology Acceptance Model (TAM) Dalam Analisi Minat Perilaku Penggunaan E-Money Pada Mahasiswa Universitas Telkom. Jurnal Mitra Manajemen Vol 3 No 2 Februari 2019

46. Yutadi, K. 2014. Pengaruh Persepsi Privasi, Persepsi Keamanan, Persepsi Kepercayaan, Persepsi Risiko, Persepsi Kegunaan dan Persepsi Kemudahan Penggunan Terhadap Minat Penggunaan E-Commerce. Skripsi. Universitas Brawijaya.

47. https://www.academia.edu/36604342/PENG GUNAAN_DIGITAL_PAYMENT_EMONEY _ELECTRONIC_MONEY_SEBAGAI_ALAT _PEMBAYARAN_MODERN

48. http://www.tribunnews.com/bisnis/2018/02/ 08/inilah-evolusi-persaingan-e-commercedi-indonesia-tahun-2017. Diunggah 8 Februari 2018 